\title{
Seismic fragility analysis of typical pre-1990 bridges due to near- and far-field ground motions
}

\author{
Araliya Mosleh $^{1} \cdot$ Mehran S. Razzaghi $^{2} \cdot$ José Jara $^{3} \cdot$ Humberto Varum $^{4}$
}

Received: 9 April 2015/Accepted: 30 January 2016/Published online: 19 February 2016

(C) The Author(s) 2016. This article is published with open access at Springerlink.com

\begin{abstract}
Bridge damages during the past earthquakes caused several physical and economic impacts to transportation systems. Many of the existing bridges in earthquake prone areas are pre-1990 bridges and were designed with out of date regulation codes. The occurrences of strong motions in different parts of the world show every year the vulnerability of these structures. Nonlinear dynamic time history analyses were conducted to assess the seismic vulnerability of typical pre-1990 bridges. A family of existing concrete bridge representative of the most common bridges in the highway system in Iran is studied. The seismic demand consists in a set of far-field and nearfield strong motions to evaluate the likelihood of exceeding the seismic capacity of the mentioned bridges. The peak ground accelerations (PGAs) were scaled and applied incrementally to the 3D models to evaluate the seismic performance of the bridges. The superstructure was assumed to remain elastic and the nonlinear behavior in piers was modeled by assigning plastic hinges in columns. In this study the displacement ductility and the PGA are selected as a seismic performance indicator and intensity
\end{abstract}

Araliya Mosleh

a_mmosleh@yahoo.com

1 Department of Civil Engineering, Faculty of Engineering, University of Aveiro, 3810-193 Aveiro, Portugal

2 Department of Civil Engineering, Faculty of Engineering, Islamic Azad University, Qazvin Branch, Qazvin, Iran

3 Department of Civil Engineering, Faculty of Engineering, University Michoacana de San Nicolas de Hidalgo, Morelia, Mexico

4 CONSTRUCT-LESE, Department of Civil Engineering, Faculty of Engineering, University of Porto, 4200-465 Porto, Portugal measure, respectively. The results show that pre-1990 bridges subjected to near-fault ground motions reach minor and moderate damage states.

Keywords Concrete bridges - Seismic vulnerability · Time history analysis · Fragility curves $\cdot$ Far-field . Near-fault

\section{Introduction}

Bridges are important components of transportation systems. Bridge failures due to extreme loading conditions such as earthquakes may cause serious impacts to transportation systems. It is necessary to evaluate the seismic vulnerability of highway bridges to assess the expected economic losses caused by damage to highway systems in the event of an earthquake. There are many different methods to assess bridge performance such as using fragility curves (FC). There are at least four methodologies for the development of seismic fragility curves, namely: expert opinion, empirical, analytical and hybrid approaches (Avsar et al. 2011; Banerjee and Shinozuka 2007; Choine et al. 2015; Mander et al. 2007; Tavares et al. 2012; Yazgan 2015). To obtain the analytical fragility curves three steps should be considered: the simulation of ground motions, the simulation of bridges, and the generation of fragility curves. The nonlinear static analysis (Banerjee and Shinozuka 2007; Dutta and Mander 1998; Loh et al. 2002; Monti and Nistico 2002; Siqueiraa et al. 2014) nonlinear dynamic time history analysis as the most time-consuming and computationally demanding (Shinozuka et al. 2000) and elastic spectral analysis as a simplest and the least time-consuming approach (Hwang et al. 2001) can be evaluate to obtain the structural response. Nielson and 
DesRoches (2007) proposed the investigation due to the vulnerability of steel and concrete girder bridges by considering nonlinear analyses (Nielson and DesRoches 2007). Choe et al. (2009) studied typical single-bent bridge in California with RC columns, by applying nonlinear static analysis. Bertero et al. (1978) reported the some effects of near-fault ground motion, but they ignored the implications in seismic design. Brown and Saiidi (2008) reported the comparative results of two substandard bridge bents tests under dynamic ground motions on the shaking tables subjected to near-fault and far-field ground motions. The effect of near-fault versus far-field ground motion on beam and column reinforcement was investigated in this study. Several parameters were used to study the effects of near-fault versus far-field ground motions and presented the near-fault caused more extensive apparent damage in the column (Brown and Saiidi 2008). Muntasir Billah et al. (2013) focused on the fragility-based seismic vulnerability assessment of retrofitted multicolumn bridge bents subjected to near-fault and far-field ground motion. Ramanathan et al. (2015) studied the evolution in design details for Californian box-girder bridges. Also, the importance of design details on the fragility of box-girder bridges is quantified in this study. Bridge damages produce both direct and indirect losses that can be extremely high (Padgett and DesRoches 2007). During the past decades several bridges damaged due to the occurrence of earthquakes (Eshghi and Ahari 2005; Eshghi and Razzaghi 2004; Ellingwood et al. 2004; Nicknam et al. 2011; Wang et al. 2009; Wang and Lee 2009; Yang et al. 2015). Hence, the expected seismic performance of bridges attracted several researchers during the last decades (Jara et al. 2011, 2013; Varum et al. 2011; Zhang et al. 2008; Lin et al. 2015).

Before the 1970s, many of the bridges were not designed for withstand earthquakes. During the 1971 San Fernando earthquake in California several bridges suffered damages (Memari et al. 2011). The Loma Prieta earthquake in 1989 caused noticeable damage to bridges. Following the Loma Prieta earthquake, substantial changes have been made to seismic design provisions of the bridges. Seven bridges collapsed during the 1994 Northridge earthquake and many others sustained damages without collapse (Housner and Thiel 1995). Performance of pre-1990 bridges revealed that these structures are seismically vulnerable. The importance of acceptable seismic behavior for bridges in transportation systems has emphasized the need for seismic safety evaluations of existing bridges. In some countries, there is a lack of detailed studies analyzing the seismic vulnerability of the pre-1990 bridges that allows conducting specific tasks to reduce economic losses in the future. Furthermore, fragility curves can incorporate the repair cost and the recovery time for evaluating the seismic performance of a highway system, and the methodology is widely applied to assess the seismic vulnerability of bridges located in areas of high seismicity (Jara et al. 2012).

The main objective of this study is analyzing the seismic vulnerability of pre-1990 bridges. As a typical bridge structure, one of the most common bridges designed and constructed in the 1980s is selected. The bridge was subjected to a family of seismic records with different dynamic characteristics. Fragility curves were determined for each set of seismic records based on 3D models and nonlinear dynamic time history analyses. The objective of this study is to evaluate the seismic performance of old concrete bridges with different column height in Iran located near and far from sources, by assessing seismic fragility curves. The results allow evaluating the expected seismic performance of the bridges.

\section{Theoretical background}

A fundamental requirement for estimating the seismic performance of a particular structure is the ability to quantify the potential for damage as a function of earthquake intensity (e.g., peak ground acceleration). A probabilistic seismic performance analysis (PSPA) based on fragility curves provides a framework to estimate the seismic performance and reliability of the structures (Ellingwood et al. 2004; Razzaghi and Eshghi 2014; Jeon et al. 2015). Fragility functions relate the probability that the demand on a particular structure exceeds its capacity to an earthquake severity measure. It can be expressed as follows:

$F r=P\left[\left(S_{\mathrm{d}} \geq S_{\mathrm{c}} \mid \mathrm{SM}\right)\right]$

where $F r=$ fragility function, $S_{\mathrm{d}}=$ structural demand, $S_{\mathrm{c}}=$ structural capacity and $\mathrm{SM}=$ earthquake severity measure. Assuming that the demand and capacity are random variables represented by a standard lognormal function, the Eq. (1) becomes:

$F r=P\left[\left(\frac{S_{\mathrm{d}}}{S_{\mathrm{c}}} \geq 1 \mid \mathrm{SM}\right)\right]=\Phi\left[\frac{1}{\beta} \ln \left(\frac{S_{\mathrm{d}}}{S_{\mathrm{c}}}\right)\right]$

where $\Phi[]=$. the standard normal distribution function and $\beta=$ logarithmic standard deviation of the variables. This assumption has been made by several researchers (Choi et al. 2004; Hancilar et al. 2013; Razzaghi and Eshghi 2014; Shinozuka et al. 2000).

According to Eq. (2), the fragility functions depend on the structural demand and the selected damage states. The structural demand was estimated by conducting nonlinear time history analyses. There are various approaches for establishing damage limit states. HAZUS provides five qualitative damage states varying from no damage to structure collapse, based on the column damages and serviceability of bridges (NIBS 1999) (Table 1). Furthermore 
Table 1 Description of bridge damage states, taken from HAZUS (NIBS 1999)

\begin{tabular}{ll}
\hline Damage states & Description \\
\hline $\begin{array}{l}\text { No damage (N) } \\
\text { Slight/minor damage }\end{array}$ & $\begin{array}{c}\text { No damage to a bridge } \\
\text { Minor cracking and spalling to the abutment, cracks in shear keys at abutments, minor spalling and cracks at hinges, } \\
\text { minor spalling at the column (damage requires no more than cosmetic repair) or minor cracking to the deck }\end{array}$ \\
$\begin{array}{l}\text { Moderate damage } \\
\text { Any column experiencing moderate cracking and spalling (column structurally still sound), any connection having } \\
\text { cracked shear keys or bent bolts, or moderate settlement of the approach }\end{array}$ \\
$\begin{array}{l}\text { Extensive damage } \\
\text { Any column degrading without collapse (column structurally unsafe), any connection losing some bearing support, or } \\
\text { Complete damage } \\
\text { major settlement of the approach }\end{array}$ \\
$\begin{array}{l}\text { Any column collapsing and connection losing all bearing support, which may lead to imminent deck collapse } \\
\end{array}$
\end{tabular}

several quantitative damage states have been suggested by various researchers based on the strain limit in the column section, crack width and repair cost (Hose et al. 2000; Karim and Yamazaki 2001; Kawashima 2000; Mander 1999). However, the displacement ductility demand is one of the most common quantitative damage parameter used for bridges (Hwang et al. 2001; Mosleh et al. 2015).

In this study, the seismic damage is classified in five damage states, as described by HAZUS (NIBS 1999). To quantify damage states, the relative displacement ductility ratio of a column is used. This variable is defined as:

$\mu_{c i}=\frac{\Delta y_{i}}{\Delta_{y 1}}$

where $\mu_{c i}=$ ductility demand at the $i$ th damage state, $\Delta_{y i}=$ relative displacement at the top of a column at the corresponding limit state $(i)$ and $\Delta_{y 1}=$ relative displacement of a column when the longitudinal reinforcing bars reach the first yield, calculated as follows:

$\Delta_{y 1}=\frac{2}{3} \varphi_{y 1} L^{2}$

where $L=$ the length from the plastic hinge to the point of contra-flexure and, $\varphi_{y 1}=$ the curvature corresponded to relative displacement of a column when the vertical reinforcing bars at the bottom of the column reaches the first yield.

Hence, $\mu_{c 1}$ denotes the first limit state corresponding to a first yield displacement ductility ratio equal to 1 . The second damage state, $\mu_{c 2}$, represents the yield displacement ductility ratio calculated as:

$\mu_{c 2}=\frac{\Delta_{2}}{\Delta_{y 1}}=\frac{\Delta_{y}}{\Delta_{y 1}}=\frac{2}{3} \frac{\varphi_{y} L^{2}}{\Delta_{y 1}}$

where $\varphi_{y}=$ the curvature corresponded to relative displacement of a column when the vertical reinforcing bars at the bottom of the column reaches the yield.

The displacement ductility corresponding to the third damage state, $\mu_{c 3}$, is the displacement ductility ratio corresponding to $\varepsilon_{\mathrm{c}}=0.004$; where $\varepsilon_{\mathrm{c}}$ is the maximum compressive strength of concrete column, hence $\Delta_{3}$ can be estimated by Eq. 6 .

$\Delta_{3}=\Delta_{2}+\theta_{\mathrm{P}}\left(L-\frac{L_{\mathrm{P}}}{2}\right)$

where $\theta_{\mathrm{P}}$ and $L_{\mathrm{P}}$ are the rotation and the plastic hinge length, respectively. The plastic hinge rotation can be calculated by Eq. 7 and the plastic hinge length can be estimated according to Priestley et al. (1996):

$\theta_{\mathrm{P}}=\left(\varphi_{3}-\varphi_{y}\right) L_{\mathrm{P}}$

$L_{\mathrm{P}}=0.08 L+0.022 f_{\mathrm{ye}} d_{\mathrm{bl}} \geq 0.044 f_{\mathrm{ye}} d_{\mathrm{bl}}$

where $f_{\mathrm{ye}}$ is the yield strength of the reinforcing bars and $d_{\mathrm{bl}}$ is the diameter of longitudinal reinforcing bars. Finally $\mu_{c 4}$ can be calculated as follows (FHWA 1995; Hwang et al. 2001):

$\mu_{c 4}=\mu_{c 3}+3$

\section{Ground motion selection}

One of the important tasks to generate fragility curves is the correct selection of input motion parameters. The intensity of an earthquake is commonly described using the peak ground acceleration (PGA). However, severe structural damages are not always related with large values of PGA. Other indexes, namely: (PGD) peak ground displacement, (PGV) peak ground velocity, (SI) spectrum intensity (Katayama et al. 1998), (Td) time duration of strong motion (Trifunac and Brady 1975), (D) distance to epicenter, and spectral characteristics, are also employed in damage estimation (Molas and Yamazaki 1995). In this study, analytical probabilistic seismic performance analyses (PSPA) are conducted based on the nonlinear response history of the bridge. All the selected seismic records have PGA greater than $0.05 \mathrm{~g}$ (Table 2). This table presents ten strong motions, five of them are near-field and the remaining are far-field records. Near-field ground motions are distinguished by a long period velocity pulse and 
Table 2 Important parameters of the selected earthquake ground motions (http://peer.berkeley.edu/peer_ground_motion_database)

\begin{tabular}{lclll}
\hline Year & $D(\mathrm{~km})$ & $M$ & PGA $(\mathrm{g})$ & Earthquake \\
\hline 1989 & 7.2 & 6.9 & 0.644 & Loma Prieta \\
1999 & 13.7 & 7.1 & 0.092 & Duzce \\
1999 & 33.2 & 7.4 & 0.376 & Kocaeli, Turkey \\
1994 & 40.7 & 6.7 & 0.568 & Northridge \\
1978 & 20.6 & 7.4 & 0.406 & Tabas \\
1990 & 40.4 & 7.4 & 0.505 & Manjil \\
1990 & 84.0 & 7.4 & 0.184 & Manjil \\
1987 & 7.5 & 6.5 & 0.793 & Superstition Hills \\
1971 & 11.8 & 6.6 & 0.699 & San Fernando \\
1976 & 55.7 & 7.2 & 0.064 & Calderan-Turkey \\
\hline
\end{tabular}

permanent ground displacement (Somerville 2002). Distance to the epicenter of the earthquake is another factor to classify ground motions as 'near-fault', the epicenter should no more than $15 \mathrm{~km}$ of the structure. All the seismic stations are located in hard soil sites and the response spectra of the motions are presented in Fig. 1. The natural period of the mentioned bridge sample analyzed is around $2.06 \mathrm{~s}$. It can be notice that the peak in the acceleration response spectra occurs at a period of around $0.5 \mathrm{~s}$. The period of the bridge falls in to the right of the period of the peak response for both near- and far-fields. However, it is observed that the natural period of the response spectra corresponded to far-field earthquakes is more than the mean values, therefor the far-field earthquakes induce a greater acceleration response. Thus, it is expected the mentioned bridge is more vulnerable to seismic effects based on far-field earthquakes.

\section{Description of the bridge}

A multi-span simply supported bridge with concrete girders considered a typical structure designed and constructed in the 1980s is selected. The bridge has six spans with a total length of $120 \mathrm{~m}$, and five frame-type bents. Each bent has three circular columns and the superstructure is composed by RC slabs supported on five precast concrete girders spaced at $3.2 \mathrm{~m}$. The span length and the bridge width are 32 and $16 \mathrm{~m}$, respectively. The cap beam is a rectangular element of $1.9 \mathrm{~m}$ by $2.0 \mathrm{~m}$ and the circular columns have a diameter of $1.4 \mathrm{~m}$. The pier heights are 15 and $18 \mathrm{~m}$. Each column has $20 \Phi 30$ vertical bars and $\Phi 18$ spiral hoops spacing $200 \mathrm{~mm}$. The gap between deck and abutment is $150 \mathrm{~mm}$ and the gap between decks in each span is of $100 \mathrm{~mm}$. The concrete girders are supported on elastomeric type bearings. The geometric characteristics of the bridge are indicated in Fig. 2.

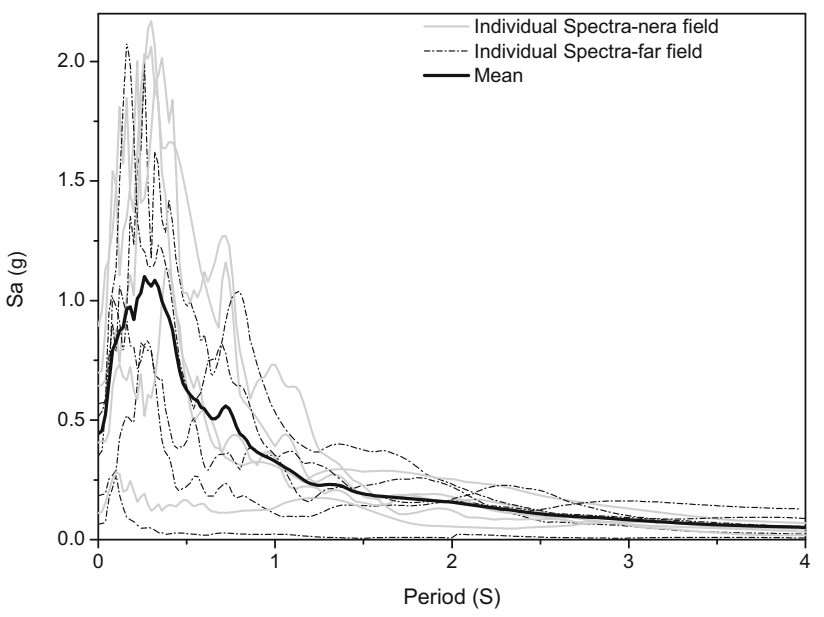

Fig. 1 Response spectra of the selected ground motions

\section{Probabilistic seismic performance analysis}

\section{Numerical analysis}

The bridges are modeled and analyzed with the SAP2000 software (CSI (SAP2000 V-14) 2009). Frame elements with six degrees of freedom at each node are used to model the columns, bent caps and girders; the deck and diaphragms are modeled with shell elements. Link elements are used to model elastomeric bearings with six degrees of freedom at each node. The nonlinear behavior of the columns is considered with a concentrated plasticity model by assigning plastic hinges at both column ends which is recommended in Caltrans code (Caltrans 2013).

\section{Development of fragility curves}

The analytical fragility curves are determined with the results of the response history analyses. The analytical model considers inelastic behavior of the columns and elastic behavior of the deck. The nonlinear time history analysis is carried out by considering the displacement ductility of the columns as limit state. Each fragility curves can be generated as lognormal distribution functions characterized by median and dispersion. Previous studies revealed the noticeable effects of near-fault ground motions on the seismic performance of bridges (Chouw and Hao 2008; Loh et al. 2002; Phan et al. 2007; Taflanidis 2011). To evaluate the importance of the seismic record type on the fragility curves, three curves for each damage state were developed, namely: fragility curves based on near-field ground motions, those developed based on farfield ground motions and fragility curves developed using combination of near- and far-field ground motions. The fragility curves present PGA in the horizontal axis and the 


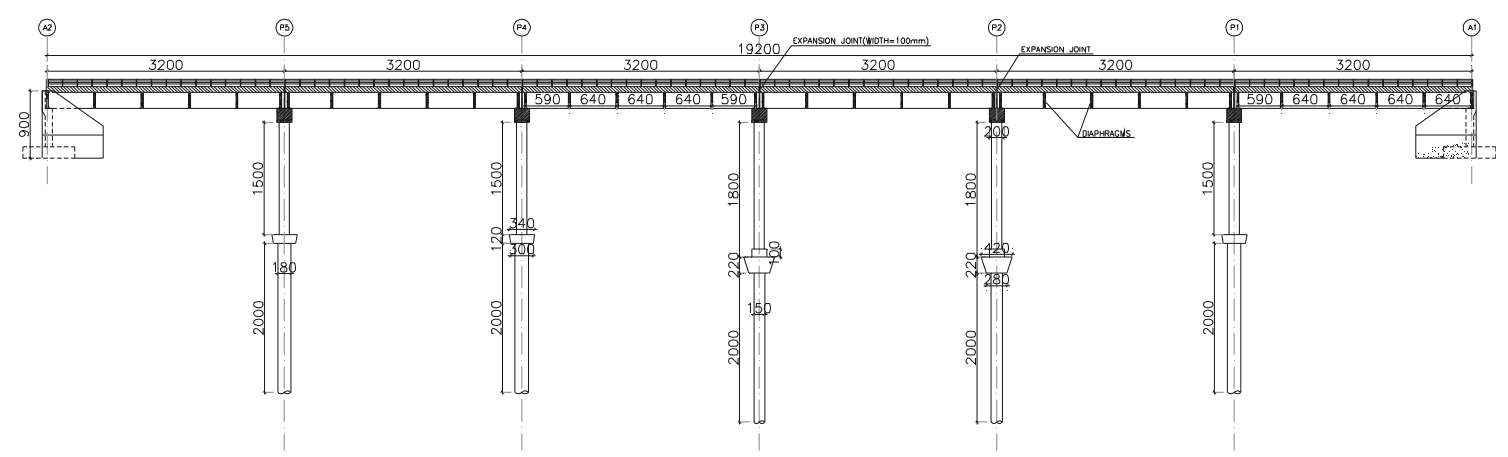

(a)
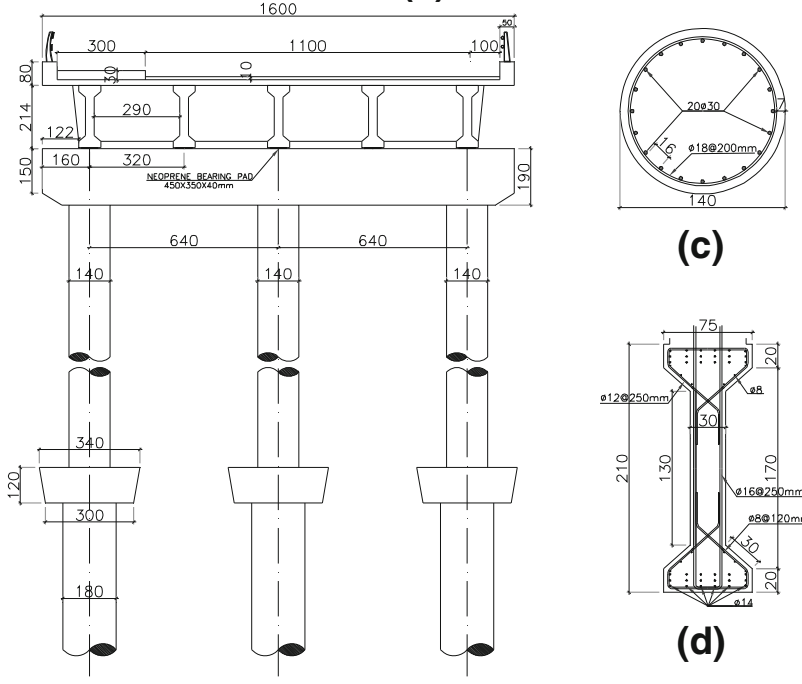

(c)

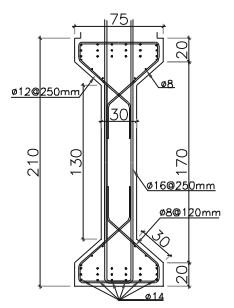

(d)

(b)

Fig. 2 a Longitudinal view of bridge, $\mathbf{b}$ bridge cross section, $\mathbf{c}$ pier cross section, $\mathbf{d}$ beam cross section

Table 3 Fragility curve parameters for near-field and far-field records

\begin{tabular}{|c|c|c|c|c|c|c|c|c|}
\hline \multirow[t]{2}{*}{ Intensity measure-PGA (g) } & \multicolumn{2}{|l|}{ LS-1 } & \multicolumn{2}{|l|}{ LS-2 } & \multicolumn{2}{|l|}{ LS-3 } & \multicolumn{2}{|l|}{ LS-4 } \\
\hline & $\mu$ & $\sigma$ & $\mu$ & $\sigma$ & $\mu$ & $\sigma$ & $\mu$ & $\sigma$ \\
\hline Far & -1.19 & 0.18 & -1.02 & 0.13 & -0.8 & 0.2 & -0.66 & 0.29 \\
\hline Near & -0.94 & 0.19 & -0.77 & 0.19 & -0.7 & 0.22 & -0.43 & 0.3 \\
\hline Total & -1.05 & 0.22 & -0.87 & 0.22 & -0.8 & 0.22 & -0.55 & 0.29 \\
\hline
\end{tabular}

probability of exceedance of a limit state in the vertical axis.

The fragility curves of a bridge display the conditional probability that the structural demand exceeds the structural capacity. Each curve depends on the median value and the dispersion parameter (lognormal standard deviation) of the capacity and the demand. For each ground motion with a specific PGA, the number of sample that reached or exceeded a specified damage limit state is obtained. The probability of exceedance is determined by dividing the number of samples that reached or exceeded the specified damage limit state to the total number of samples. After performing the similar evaluation for each ground motion and the four damage limit states, the probability of reaching or exceeding the damage limit states is obtained.

Assuming a lognormal density function of the capacity and the demand, the fragility curves are lognormal distributed with the parameters presented in Table 3. These parameters are the results of the nonlinear time history analyses of the bridge subjected to the family of seismic records previously mentioned for each of the limit states.

Figure 3 shows the fragility curves developed based on both near- and far-field ground motions. In this graph LS1, LS2, LS3, and LS4 are: slight, moderate, extensive and complete damage state (collapse), respectively.

If the probability of exceeding a damage performance increased, some mitigation plan should be made in 
advance. In the limit state of slight damage, minor damage may happen and it is expected that with only small repairs the bridge can be use normally. The difference between the fragility curves for the damage limit states LS2 and LS3 is relatively small. One of the main reasons for this small

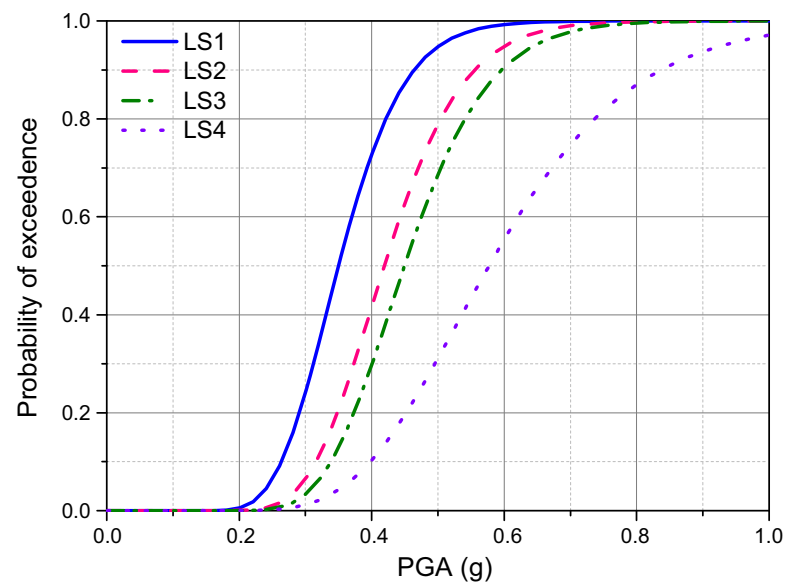

Fig. 3 Bridge system fragility curves for the multi-span simply supported bridge

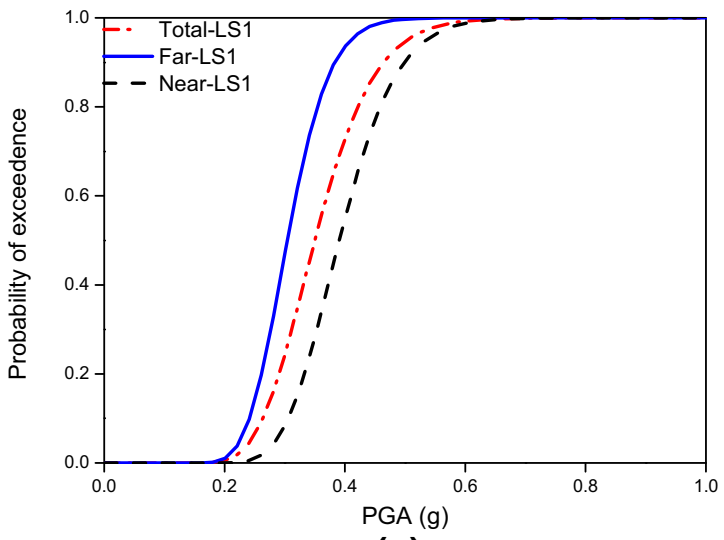

(a)

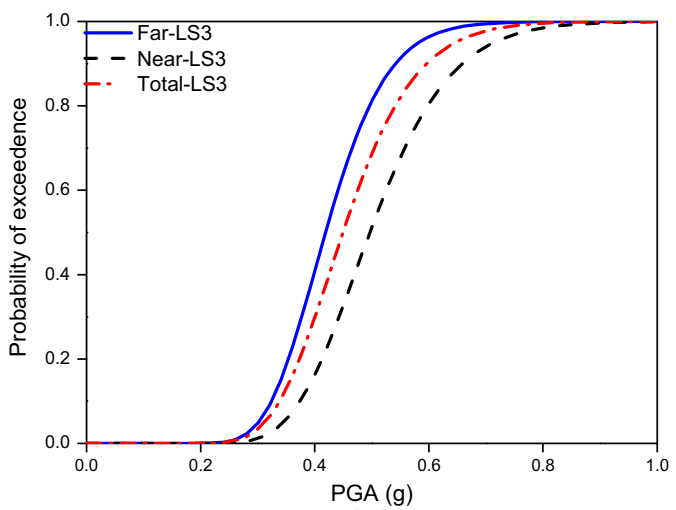

(c) difference is the acceptance criteria definitions of the corresponding damage limit states (1.26 corresponded to LS2 and 1.49 related to LS3).

As indicated in Fig. 3, for PGA $=0.5 \mathrm{~g}$ (for example) the probability of collapse of the bridge is $30 \%$. The probability of reaching or exceeding the LS1, LS2 and LS3 are 92,80 , and $68 \%$ respectively. In other words, the fragility curves developed in this study indicate that the selected typical pre-1990 bridges are seismically vulnerable. Figure 4 displays the curves for the two groups of accelerograms and four limit states. Each graph presents three fragility curves to evaluate the effect of the different seismic records on the fragility curves.

The bridge was more vulnerable to the far-field accelerograms, which means that the mentioned bridge is more vulnerable to seismic effects due to far-field earthquakes than near faults. This outcome is consistent with the response of the bridge observed in the earthquakes in farfield. It seems that the bridge location in relation of the epicenter does not impact importantly the fragility curves.

Figure 5 shows the column displacement demands versus the PGA for far-field, near-field, all the seismic records and mead values from elastic behavior through yielding to

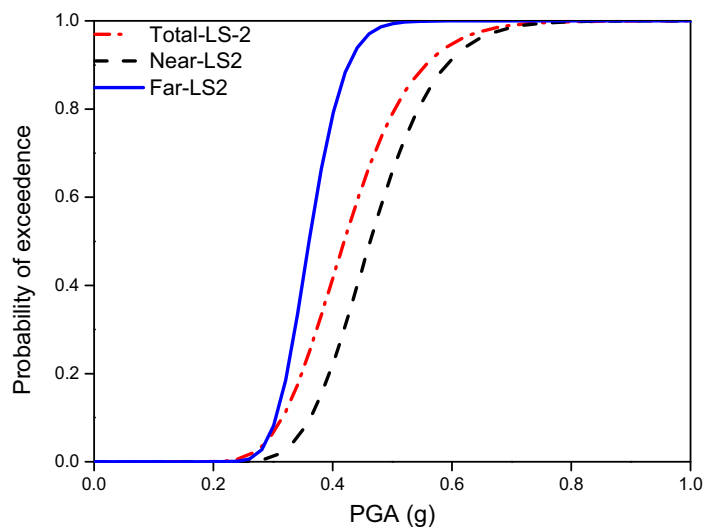

(b)

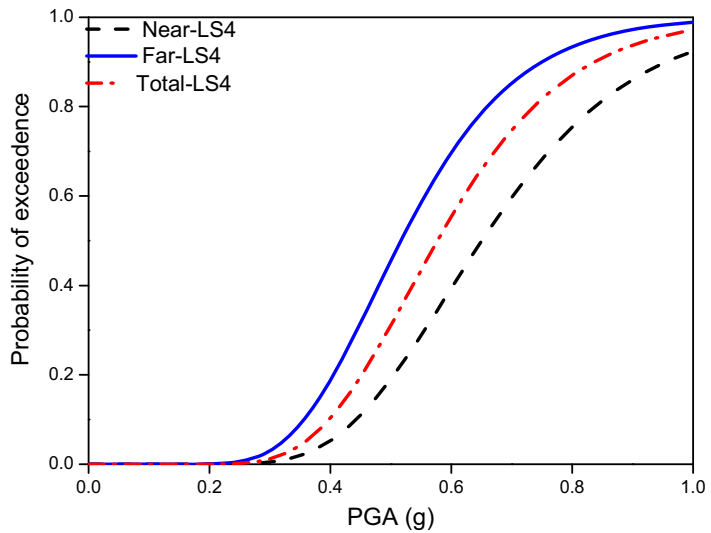

(d)

Fig. 4 Fragility curves between a slight, $\mathbf{b}$ moderate, $\mathbf{c}$ extensive and $\mathbf{d}$ complete damage limit state 


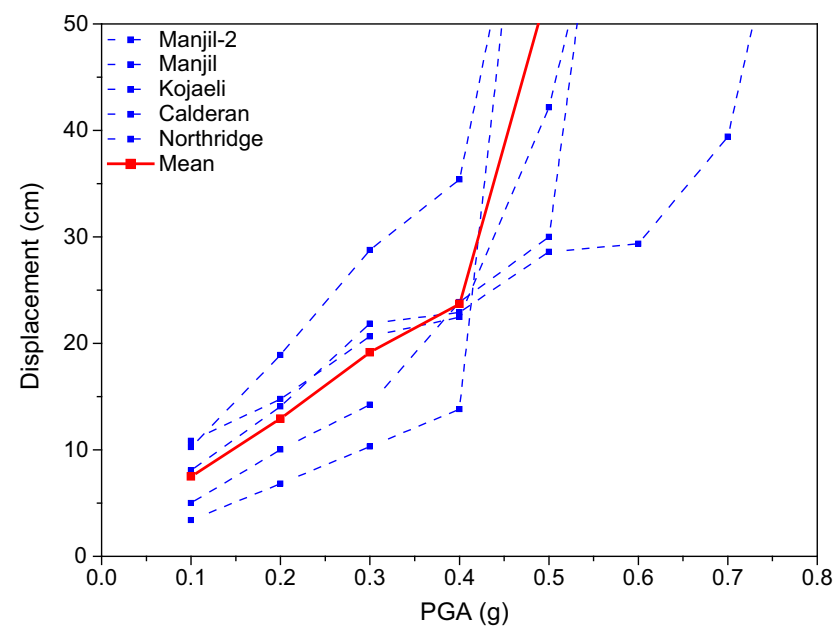

(a)

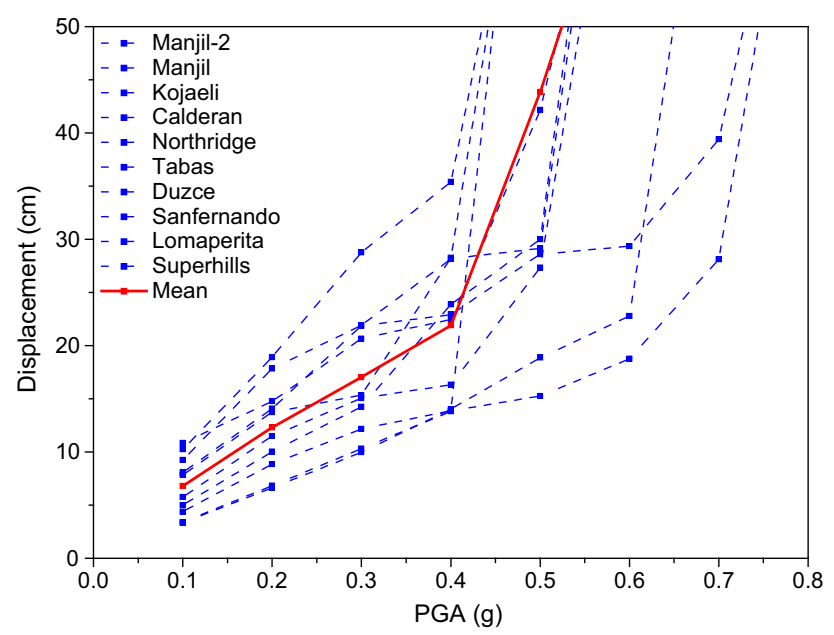

(c)

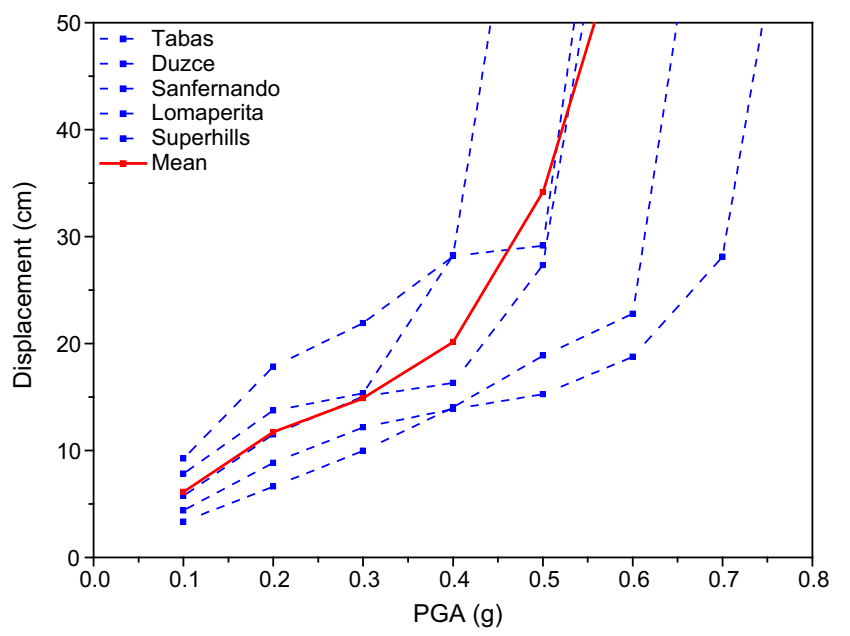

(b)

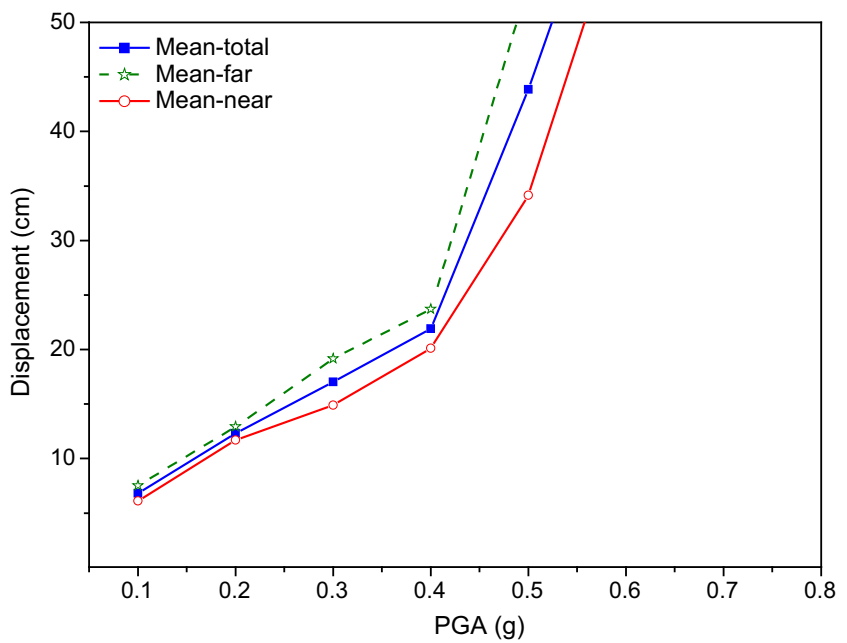

(d)

Fig. 5 Incremental displacement $\mathbf{a}$ far-field, $\mathbf{b}$ near-field, $\mathbf{c}$ all seismic records and $\mathbf{d}$ mean values

dynamic instability or until a limit state failure occurs. Some records produce gradually increments of the displacement demands with the PGA increases and others, like the Kocaeli seismic record, increases suddenly the displacements after a PGA value $(0.4 \mathrm{~g})$. For near-field earthquakes, large displacements appears after $\mathrm{PGA}=0.5 \mathrm{~g}$ in most of the cases. From Fig. $4 \mathrm{~d}$ it can be observed that the variation of displacement is linear and bridge is in linear zone up to PGA $=0.4 \mathrm{~g}$, while after $\mathrm{PGA}=0.5 \mathrm{~g}$ the bridge is subjected to nonlinearity.

\section{Conclusions}

Fragility curves are a useful tool to estimate the expected damages of bridge structures. The aim of a vulnerability assessment of bridges is to execute preventive actions to plan a disaster response, create a retrofit program, estimate future economic losses, and evaluate the loss of functionality of highway transportation systems. This study presents the generation of fragility curves for one of the most common bridge typologies in high seismic zone areas designed with old codes, and compares the effect of sourceto-site distance of group of records. Nonlinear dynamic analyses were carried out to determine the seismic performance of a typical pre-1990 RC bridge subjected to three groups of seismic records: far-field accelerograms, near-field accelerograms and all the seismic records. Earthquake records from some major event e.g., the 1989 Loma perita, the San Fernando 1971, the 1994 Northridge, and some earthquakes recorded in Iran namely: the 1990 Manjil, the 1978 Tabas, were selected as the input ground motions. Analytical fragility curves for the bridge were obtained using the PGA as an intensity measure. The 
fragility curves for near-fault and far-field sources represent limit states of behavior as a function of the displacement ductility demands on columns. The following conclusions are based on the nonlinear dynamic analyses of the bridge subjected to 70 earthquake records.

- The fragility curves of this study correspond to one of the common class bridges in Iran. It can be used for other type of bridges to determine the seismic risk associated.

- The fragility curves can be used to evaluate potential losses of bridges with the same typology of the analyzed structure. The results showed that far-fields seismic records dominated, while the impact of the near-fields earthquake data bases is reduced.

- Results revealed that the selected typical pre-1990 bridges are seismically vulnerable.

- The columns were the only structural element analyzed in this study; as suggestion for future research the bearings, abutments and the foundation could be included to develop fragility curves.

Acknowledgments The authors would like to thank the anonymous reviewers for their constructive comments.

Open Access This article is distributed under the terms of the Creative Commons Attribution 4.0 International License (http://crea tivecommons.org/licenses/by/4.0/), which permits unrestricted use, distribution, and reproduction in any medium, provided you give appropriate credit to the original author(s) and the source, provide a link to the Creative Commons license, and indicate if changes were made.

\section{References}

Avsar O, Yakut A, Caner A (2011) Analytical fragility curves for ordinary highway bridges in Turkey. Earthq Spectra 27:971-996

Banerjee S, Shinozuka M (2007) Nonlinear static procedure for seismic vulnerability assessment of bridges. Comput Aided Civil Infrastruct 22:293-305

Bertero VV, Mahin SA, Herrera RA (1978) A seismic design implications of near-fault San Fernando earthquake record. Earthq Eng Struct Dyn 6:21-42

Brown AS, Saiidi MS (2008) Investigation of near-fault vs. far field ground motion effects on a substandard bridge bent. Report University of Nevada, Reno

Caltrans (2013) Seismic design criteria, Version 1.7. California Department of Transportation, Sacramento, CA

Choe D, Gardoni P, Rosowsky D, Haukaas T (2009) Seismic fragility estimates for reinforced concrete bridges subject to corrosion. Struct Saf 31:275-283

Choi E, DesRoches R, Nielson B (2004) Seismic fragility of typical bridges in moderate seismic zones. Eng Struct 26:187-199

Choine M, Connor A, Padgett J (2015) Comparison between the seismic performance of integral and jointed concrete bridges. J Earthq Eng 19:172-191

Chouw N, Hao H (2008) Significance of SSI and nonuniform nearfault ground motions in bridge response: effect on response with conventional expansion joint. Eng Struct 30:141-153
CSI (SAP2000 V-14) (2009) Integrated finite element analysis and design of structures basic analysis reference manual. Computers and Structures Inc., Berkeley, CA

Dutta A, Mander JB (1998) Seismic fragility analysis of highway bridges. Tokyo, Japan, 22-23 June

Ellingwood BR, Rosowsky DV, Li Y, Kim JH (2004) Fragility assessment of light-frame wood construction subjected to wind and earthquake hazards. J Struct Eng. doi:10.1061/(ASCE)07339445(2004)130:12(1921)

Eshghi S, Ahari MN (2005) Performance of transportation systems in the 2003 Bam, Iran, earthquake. Earthq Spectra 21:455-468

Eshghi S, Razzaghi MS (2004) The behavior of special structures during the Bam earthquake of 26 December 2003. JSEE Spec Issue Bam Earthq 5:197-207

FHWA (1995) Seismic retrofitting manual for highway bridges publication no. FHWA-RD-94-052. Office of Engineering and Highway Operations R\&D, Federal Highway Administration, McLean, VA

Hancilar U, Taucer F, Corbane C (2013) Empirical fragility functions based on remote sensing and field data after the 12 January 2010 Haiti earthquake. Earthq Spectra 29:1275-1310

Hose Y, Silva P, Seible F (2000) Development of a performance evaluation database for concrete bridge components and systems under simulated seismic loads. Earthq Spectra 16:413-442

Housner GW, Thiel CC (1995) The continuing challenge: report on the performance of state bridges in the Northridge earthquake. Earthq Spectra 11:607-636

Hwang H, Liu J, Chiu Y (2001) Seismic fragility analysis of highway bridges. Center for Earthquake Research and Information, The University of Memphis, MAEC RR-4 Project

Jara JM, Galvan A, Jara M, Olmos B (2011) Procedure for determining the seismic vulnerability of an irregular isolated bridge. Struct Infrastruct Eng 9(6):1-13

Jara JM, Jara M, Olmos B, Villanueva D, Varum H (2012) Expected seismic performance of irregular isolated bridges. In: Proceedings of the sixth international IABMAS conference. Bridge maintenance, safety, management, resilience and sustainability, Italy

Jara JM, Jara M, Hernández H, Olmos BA (2013) Use of sliding multirotational devices of an irregular bridge in a zone of high seismicity. KSCE J Civil Eng 17:122-132

Jeon J, Shafieezadeh A, Lee D, Choi E, DesRoches R (2015) Damage assessment of older highway bridges subjected to three-dimensional ground motions: characterization of shear-axial force interaction on seismic fragilities. Eng Struct 87:47-57

Karim KR, Yamazaki F (2001) Effect of earthquake ground motions on fragility curves of highway bridge piers based on numerical simulation. Earthq Eng Struct Dyn 30:1839-1856

Katayama T, Sato N, Saito K (1998) SI-sensor for the identification of destructive earthquake ground motion. Paper presented at the proceedings of the 9 th world conference on earth engineering

Kawashima K (2000) Seismic design and retrofit of bridges. Paper presented at the proceedings of 12WCEE, New Zealand

Lin Z, Yan F, Azimi M, Azarmi F, Al-Kaseasbeh Q (2015) A revisit of fatigue performance based welding quality criteria in bridge welding provisions and guidelines. Paper presented at the international industrial informatics and computer engineering conference (IIICEC), Shaanxi, China

Loh CH, Liao WI, Chai JF (2002) Effect of near-fault earthquake on bridges: lessons learned from Chi-Chi earthquake. Earthq Eng Eng Vib 1:86-93

Mander JB (1999) Fragility curve development for assessing the seismic vulnerability of highway bridges. University at Buffalo, State University of New York, MCEER Highway Project/FHWA

Mander J, Dhakal R, Mashiko N, Solberg K (2007) Incremental dynamic analysis applied to seismic financial risk assessment of bridges. Eng Struct 29:2662-2672 
Memari AM, Harris HG, Hamid AA (2011) Seismic evaluation of reinforced concrete piers in low to moderate seismic regions. Electron J Struct Eng 11:57-68

Molas GL, Yamazaki F (1995) Neural networks for quick earthquake damage estimation. Earthq Eng Struct Dyn 24:505-516

Monti G, Nistico N (2002) Simple probability-based assessment of bridges under scenario earthquakes. J Bridge Eng 7:104-114

Mosleh A, Varum H, Jara J (2015) A methodology for determining the seismic vulnerability of old concrete highway bridges by using fragility curves. J Struct Eng Geotech 5(1):1-7

Muntasir Billah AHM, Shahria Alam M, Rahman Bhuiyan MA (2013) Fragility analysis of retrofitted multi-column bridge bent subjected to near fault and far field ground motion. J Bridge Eng. doi:10.1061/(ASCE)BE.1943-5592.0000452

NIBS (1999) Vol 2. Earthquake loss methodology, HAZUS 99, Technical manual. Washington DC, USA

Nicknam A, Mosleh A, Hamidi H (2011) Seismic performance evaluation of urban bridge using static nonlinear procedure, case study: Hafez Bridge. Proc Eng 14:2350-2357

Nielson BG, DesRoches R (2007) Analytical seismic fragility curves for typical bridges in the central and southeastern United States. Earthq Spectra 23:615-633

Padgett JE, DesRoches R (2007) Bridge functionality relationships for improved seismic risk assessment of transportation networks. Earthq Spectra 23:115-130

Phan V, Saiidi MS, Anderson J, Ghasemi H (2007) Near-fault ground motion effects on reinforced concrete bridge columns. J Struct Eng 133:982-989

Priestley MJN, Calvi GM (1996) Seismic design and retrofit of bridges. Wiley, New York

Ramanathan K, Padgettb J, DesRoches R (2015) Temporal evolution of seismic fragility curves for concrete box-girder bridges in California. Eng Struct 97:29-46

Razzaghi MS, Eshghi S (2014) Probabilistic seismic safety assessment of precode cylindrical oil tanks. J Perform Construct Facil (ASCE). doi:10.1061/(ASCE)CF.1943-5509.0000669

Shinozuka M, Feng MQ, Lee J, Naganuma T (2000) Statistical analysis of fragility curves. J Eng Mech 126:1224-1231
Siqueiraa G, Sandab A, Paultreb P, Padgettc J (2014) Fragility curves for isolated bridges in eastern Canada using experimental results. Eng Struct 74:311-324

Somerville PG (2002) Characterizing near fault ground motion for the design and evaluation of bridges. Paper presented at the third national conference and workshop on bridges and highways, Portland, Oregon

Taflanidis A (2011) Optimal probabilistic design of seismic dampers for the protection of isolated bridges against near-fault seismic excitations. Eng Struct 33:3496-3508

Tavares DH, Padgett JE, Paultre P (2012) Fragility curves of typical as-built highway bridges in eastern Canada. Eng Struct 40:107-118

Trifunac MD, Brady AG (1975) A study of the duration of strong earthquake ground motion. Bull Seismol Soc Am 65:581-626

Varum H, Sousa R, Delgado W, Fernandes C, Costa A, Jara JM, Álvarez JJ (2011) Comparative structural response of two steel bridges constructed 100 years apart. Struct Infrastruct Eng 7:843-855

Wang Z, Lee GC (2009) A comparative study of bridge damage due to the Wenchuan, Northridge, Loma Prieta and San Fernando earthquakes. Earthq Eng Eng Vib 8:251-261

Wang D, Guo X, Sun Z, Meng Q, Yu D, Li X (2009) Damage to highway bridges during Wenchuan earthquake. J Earthq Eng Eng Vib 3:84-94

Yang C, Werner S, DesRochesa R (2015) Seismic fragility analysis of skewed bridges in the central southeastern United States. Eng Struct 83:116-128

Yazgan U (2015) Empirical seismic fragility assessment with explicit modeling of spatial ground motion variability. Eng Struct 100:479-489

Zhang Y, Conte JP, Yang Z, Elgamal A, Bielak J, Acero G (2008) Two-dimensional nonlinear earthquake response analysis of a bridge-foundation-ground system. Earthq Spectra 24:343-386 